\title{
Isoproterenol Sulfate
}

National Cancer Institute

\section{Source}

National Cancer Institute. Isoproterenol Sulfate. NCI Thesaurus. Code C65983.

The sulfate salt form of isoproterenol, a beta-adrenergic receptor agonist with bronchodilator activity. Isoproterenol binds to beta-2 adrenergic receptors in bronchial smooth muscle, thereby activating intracellular adenyl cyclase, an enzyme that catalyzes the conversion of adenosine triphosphate (ATP) to cyclic-3',5'-adenosine monophosphate (CAMP). Increased cAMP levels cause relaxation of bronchial smooth muscle, relieve bronchospasms, improve mucociliary clearance and inhibit the release of mediators of immediate hypersensitivity from cells, especially from mast cells. 